\title{
Porcine endogenous retroviruses: an obstacle to cross during xenotransplantation
}

\author{
Subramaniam Senthilkumar, Soma Guharthakurta, Kotturathu Mammen Cherian \\ From First International Science Symposium on HIV and Infectious Diseases (HIV SCIENCE 2012) \\ Chennai, India. 20-22 January 2012
}

\section{Background}

Xenotransplantation involves the transplantation of nonhuman tissue or organs to humans. Worldwide shortage of organs for clinical applications has shifted the focus towards non-human sources. Pig represents a rich source of organ donors but the presence of porcine endogenous retroviruses (PERVs) represents a particular risk and considered as a major obstacle during xenotransplantation. Among various types; PERV-C may recombine to form recombinant PERV-A/C and has the ability to infect human cells invitro and replicate at high titers. Our study aims to screen porcine tissue samples for provirus and virus particles of PERVs by PCR and reverse transcriptase PCR (RT-PCR).

\section{Methods}

A total of 23 porcine heart tissue samples were included in this study. DNA and RNA from tissue samples were extracted using DNA and RNA extraction kits respectively. All the samples were subjected to standard PCR to detect pro-viral DNA and RT-PCR for mRNA expression of virus particle using specific primers.

\section{Results}

All the $23(100 \%)$ samples tested were positive for PERV-A and B pro-viral DNA by standard PCR, while 20/23 (87\%) samples were positive for PERV-A and B RNA by RT-PCR. Fifteen out of $23(65.2 \%)$ and 5/23 (21.7\%) samples were positive for PERV-C and PERV-A/ C pro-viral DNA respectively. Five out of $23(21.7 \%)$ and $3 / 23(13 \%)$ samples were positive for PERV-C and PERV-A/C RNA respectively.

*Correspondence: sentmicbio@gmail.com

Frontier Lifeline Pvt. Ltd., Chennai, India

\section{Conclusion}

Low prevalence of PERV-C in our study indicates and paves a way to cross the obstacle in xeno-transplantation by using PERV-C free animal which may not produce infectious PERV-A/C recombinant virus.

Published: 4 May 2012

doi:10.1186/1471-2334-12-S1-012

Cite this article as: Senthilkumar et al:: Porcine endogenous retroviruses: an obstacle to cross during xenotransplantation. BMC Infectious Diseases 2012 12(Suppl 1):012.
Submit your next manuscript to BioMed Central and take full advantage of:

- Convenient online submission

- Thorough peer review

- No space constraints or color figure charges

- Immediate publication on acceptance

- Inclusion in PubMed, CAS, Scopus and Google Scholar

- Research which is freely available for redistribution
( Biomed Central 